\title{
EXPERIMENTAL STUDIES ON REPLACEMENT OF CEMENT WITH CHALK POWDER AND COCONUT FIBER IN CONVENTIONAL CONCRETE
}

\author{
Vineet Singh $\mathbf{T}^{\mathbf{1}}$, Tiwari Rakesh Prasad ${ }^{2}$, Sure Mounika ${ }^{3}$, Vemula Sujeeth Kumar Reddy ${ }^{4}$ \\ ${ }^{1}$ Student, Civil Engineering, Guru Nanak Institutions Technical Campus, Telangana, India \\ ${ }^{2}$ Student, Civil Engineering, Guru Nanak Institutions Technical Campus, Telangana, India \\ ${ }^{3}$ Student, Civil Engineering, Guru Nanak Institutions Technical Campus, Telangana, India \\ ${ }^{4}$ Student, Civil Engineering, Guru Nanak Institutions Technical Campus, Telangana, India
}

\begin{abstract}
The materials chosen for construction should be pollution and should not endanger the resources. They should be conveniently used by the ordinary people and be low in monetary cost. Coconut fiber and chalk powder are abundant, versatile, renewable and cheap. Reusing of chalk powder reduces the waste released by various schools, colleges and educational institutions. Coconut Fiber is light in weight and is consistent in high quality. The aim of this experimental study was to check whether there is a possibility of using the coconut fiber and chalk powder in addition to the other constituents of concrete and to study the strength properties. In the present study the deformation properties of concrete cubes under static loading condition and the behavior of structural components in terms of compressive strength for conventional concrete $(C C)$, chalk powder reinforced concrete $(C P R C)$ and coconut fiber reinforced concrete (CFRC) has been studied. In this project we have prepared 21 cubes out of which 3 are CC, 3 CPRC(1\%), 3 CPRC(2\%), 3 CPRC (3\%), 3 CFRC(1\%), 3 CFRC(2\%), 3 CFRC(3\%). To identify the effects on workability, workability tests such slump cone test was conducted on the cubes prepared by conventional concrete, chalk powder and coconut fiber. The standard cubes for CC, CPRC and CFRC were casted and tested under CTM (compression testing machine). We conclude that there is a decrement by $4.4 \%$ in compressive strength of $C P(1 \%)$ when compared to CC. There is a decrement by $2.8 \%$ in compressive strength of $C P(2 \%)$ when compared to $C C$. There is a decrement by $8.4 \%$ in compressive strength of $C P$ (3\%) when compared to CC. There is a decrement by $2 \%$ in compressive strength of CF (1\%) when compared to CC. There is a increment by $1.7 \%$ in compressive strength of $C F(2 \%)$ when compared to CC. There is a increment by $4.2 \%$ in compressive strength of $C F(3 \%)$ when compared to $C C$.
\end{abstract}

Keywords: CC-conventional concrete, $C P R C$ - chalk powder reinforced concrete, $C F R C$-coconut fiber reinforced concrete, $C P$ - Chalk Powder, $C F-$ Coconut fiber $* * *$

\section{INTRODUCTION}

Concrete is a mixture of paste and aggregates, or rocks. The paste, composed of Portland cement and water, coats the surface of the fine (small) and coarse (larger) aggregates. Concrete production is the process of mixing together the various ingredients - water, aggregate, cement, and any additives - to produce concrete. Concrete production is time-sensitive.

\subsection{Benefits of Chalk Powder}

- Prevent silver and jewellery from tarnishing.

- Chalk Powder can be used for the design of the floor when your redecorating.

- Rub some chalk powder on the flat head of screwdriver to prevent slipping.

- Rub some chalk powder to cover up temporary water and scuff marks on the ceiling until you permanently paint it.

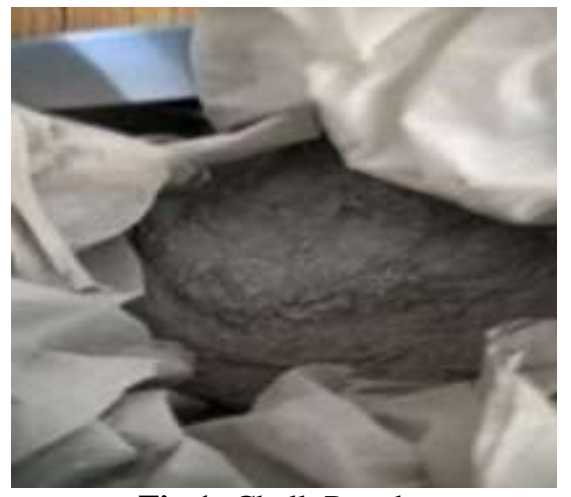

Fig 1: Chalk Powder

\subsection{Benefits of Coconut Fiber}

- Coconut fiber is $100 \%$ renewable resource.

- Coconut fiber is environmentally friendly.

- Coconut fiber never shrinks, cracks or produces crust.

- Coconut fiber is odorless, pleasant to handle, uniform in composition.

- Coconut fiber has ideal $\mathrm{pH}$ in the range of 6-6.7. 
- It is a biodegradable source that degrades very slowly and has a life of three to four years.

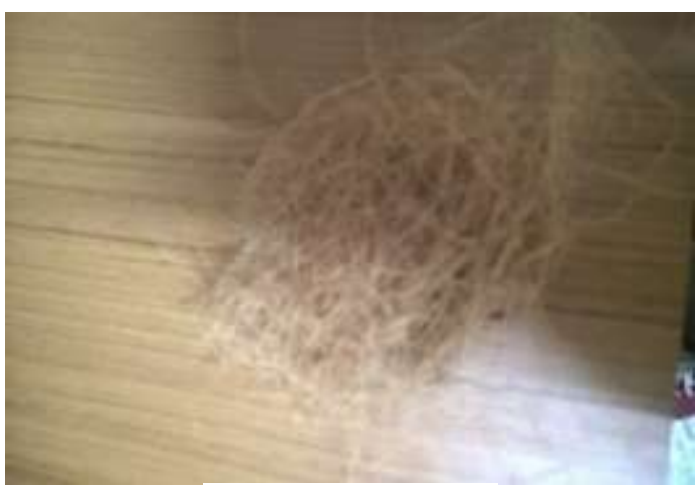

Fig 2: Coconut Fiber

\section{NOMINAL MIX DESIGN}

* Assuming W/C ratio $=0.5$. ( Pg no 415 From Concrete Technology by MS Shetty Text book)

* Maximum W/C ratio for M20 reinforced concrete = 0.55. (10262 - 1989 Code book)

* For $1 \mathrm{~m}^{3}$ of concrete 186 liters of water is required.( $\mathrm{Pg}$ no 493 from Concrete Technology by MS Shetty Text book)

Hence water content $=186 \mathrm{l} / \mathrm{m}^{3}$

$\mathrm{W} / \mathrm{C}$ ratio $=0.5$

Cement content $=$ water content $/ \mathrm{W} / \mathrm{C}$ ratio

Cement content $=186 / 0.5=372 \mathrm{~kg} / \mathrm{m}^{3}$

* For M20 grade of concrete = 1:1.5:3

Where $1=$ Cement content

$1.5=$ Fine aggregate content

3 = Coarse aggregate content

Hence fine aggregate content $=1.5 \times 372=558 \mathrm{~kg} / \mathrm{m}^{3}$

Coarse aggregate content $=3 \times 372=1116 \mathrm{~kg} / \mathrm{m}^{3}$

Table 1: Mix Design Proportions for Conventional concrete for $1 \mathrm{~m}^{3}$

\begin{tabular}{|l|l|l|l|l|}
\hline $\begin{array}{l}\text { W/C } \\
\text { ratio }\end{array}$ & Cement & $\begin{array}{l}\text { Fine } \\
\text { aggregate }\end{array}$ & $\begin{array}{l}\text { Coarse } \\
\text { Aggregate }\end{array}$ & Water \\
\hline 0.5 & $\begin{array}{l}372 \\
\mathrm{~kg} / \mathrm{m}^{3}\end{array}$ & $558 \mathrm{~kg} / \mathrm{m}^{3}$ & $1116 \mathrm{~kg} / \mathrm{m}^{3}$ & 1861 \\
\hline
\end{tabular}

* Conventional concrete (CC): Size of a cube according to code book is $150 \mathrm{~mm} \times 150 \mathrm{~mm} \times 150 \mathrm{~mm}$

But for $1 \mathrm{~m}^{3}$ we require

$372 \mathrm{~kg}$ of cement

$558 \mathrm{~kg}$ of fine aggregate

$1116 \mathrm{~kg}$ of coarse aggregate

1861 of water

But for $150 \mathrm{~mm} \times 150 \mathrm{~mm} \times 150 \mathrm{~mm}$ cube

We require

Cement $=0.15 \times 0.15 \times 0.15 \times 372=1.3 \mathrm{~kg}$

Fine aggregate $=0.15 \times 0.15 \times 0.15 \times 558=1.9 \mathrm{~kg}$

Coarse aggregate $=0.15 \times 0.15 \times 0.15 \times 1116=3.8 \mathrm{~kg}$

Water $=0.15 \times 0.15 \times 0.15 \times 186=0.61$
Table 2: Mix Design Proportions for 1 Conventional

concrete cube of size $150 \mathrm{~mm} \times 150 \mathrm{~mm} \times 150 \mathrm{~mm}$

\begin{tabular}{|l|l|l|l|l|}
\hline $\begin{array}{l}\text { W/C } \\
\text { ratio }\end{array}$ & Cement & $\begin{array}{l}\text { Fine } \\
\text { Aggregate }\end{array}$ & $\begin{array}{l}\text { Coarse } \\
\text { Aggregate }\end{array}$ & Water \\
\hline 0.5 & $1.3 \mathrm{~kg}$ & $1.9 \mathrm{~kg}$ & $3.8 \mathrm{~kg}$ & 0.61 \\
\hline
\end{tabular}

For 3 cubes

We require

Cement $=1.3 \times 3=3.9 \mathrm{~kg}$

Fine aggregate $=1.9 \times 3=5.7 \mathrm{~kg}$

Coarse aggregate $=3.8 \times 3=11.4 \mathrm{~kg}$

Water $=0.6 \times 3=1.81$

Table 3: Mix Design Proportions for 3 Conventional concrete cubes of sizes $150 \mathrm{~mm} \times 150 \mathrm{~mm} \times 150 \mathrm{~mm}$

\begin{tabular}{|l|l|l|l|l|}
\hline $\begin{array}{l}\text { W/C } \\
\text { ratio }\end{array}$ & Cement & $\begin{array}{l}\text { Fine } \\
\text { Aggregate }\end{array}$ & $\begin{array}{l}\text { Coarse } \\
\text { Aggregate }\end{array}$ & Water \\
\hline 0.5 & $3.9 \mathrm{~kg}$ & $5.7 \mathrm{~kg}$ & $11.4 \mathrm{~kg}$ & 1.81 \\
\hline
\end{tabular}

Slump $=20 \mathrm{~mm}$

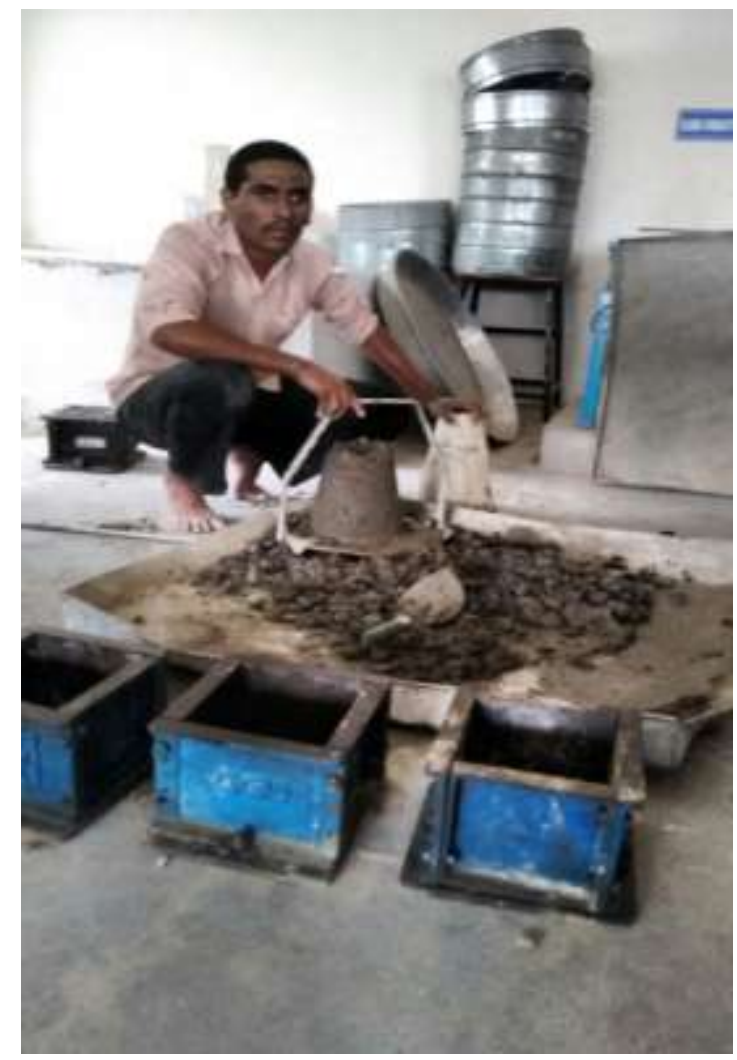

Fig 3: Slump cone test

\subsection{Replacement of Chalk Powder with Cement}

\subsection{1 $1 \%$ Replacement}

For 3 cubes we require

Cement $=1300 \mathrm{~g}-13 \mathrm{~g}=1287 \mathrm{~g}$

$=1287 \times 3=3861 \mathrm{~g}=3.86 \mathrm{~kg}$

Chalk $=13 \times 3=39 \mathrm{~g}$

Fine aggregate $=1.9 \times 3=5.7 \mathrm{~kg}$

Coarse aggregate $=3.8 \times 3=11.4 \mathrm{~kg}$

Water $=0.6 \times 3=1.81$ 
Table 4: Mix Design Proportions for 3 cubes of sizes $150 \mathrm{~mm} \times 150 \mathrm{~mm} \times 150 \mathrm{~mm}$ for $1 \%$ replacement of chalk powder with cement

\begin{tabular}{|l|l|l|l|l|l|}
\hline $\begin{array}{l}\text { W/C } \\
\text { ratio }\end{array}$ & Cement & $\begin{array}{l}\text { Chalk } \\
\text { powder }\end{array}$ & $\begin{array}{l}\text { Fine } \\
\text { Aggregate }\end{array}$ & $\begin{array}{l}\text { Coarse } \\
\text { Aggregate }\end{array}$ & Water \\
\hline 0.5 & $3.86 \mathrm{~kg}$ & $39 \mathrm{~g}$ & $5.7 \mathrm{~kg}$ & $11.4 \mathrm{~kg}$ & 1.81 \\
\hline
\end{tabular}

Slump $=25 \mathrm{~mm}$

\subsection{2 $2 \%$ Replacement}

For 3 cubes we require

Cement $=1300 \mathrm{~g}-26 \mathrm{~g}=1274 \mathrm{~g}$

$=1274 \times 3=3822 \mathrm{~g}=3.82 \mathrm{~kg}$

Chalk $=26 \times 3=78 \mathrm{~g}$

Fine aggregate $=1.9 \times 3=5.7 \mathrm{~kg}$

Coarse aggregate $=3.8 \times 3=11.4 \mathrm{~kg}$

Water $=0.6 \times 3=1.81$

Table 5: Mix Design Proportions for 3 cubes of sizes $150 \mathrm{~mm} \times 150 \mathrm{~mm} \times 150 \mathrm{~mm}$ for $2 \%$ replacement of chalk powder with cement

\begin{tabular}{|l|l|l|l|l|l|}
\hline $\begin{array}{l}\text { W/C } \\
\text { ratio }\end{array}$ & Cement & $\begin{array}{l}\text { Chalk } \\
\text { powder }\end{array}$ & $\begin{array}{l}\text { Fine } \\
\text { Aggregate }\end{array}$ & $\begin{array}{l}\text { Coarse } \\
\text { Aggregate }\end{array}$ & Water \\
\hline 0.5 & $3.82 \mathrm{~kg}$ & $78 \mathrm{~g}$ & $5.7 \mathrm{~kg}$ & $11.4 \mathrm{~kg}$ & 0.61 \\
\hline $\begin{array}{l}\mathrm{W} / \mathrm{C} \\
\text { ratio }\end{array}$ & Cement & $\begin{array}{l}\text { Chalk } \\
\text { powder }\end{array}$ & $\begin{array}{l}\text { Fine } \\
\text { Aggregate }\end{array}$ & $\begin{array}{l}\text { Coarse } \\
\text { Aggregate }\end{array}$ & Water \\
\hline 0.5 & $3.82 \mathrm{~kg}$ & $78 \mathrm{~g}$ & $5.7 \mathrm{~kg}$ & $11.4 \mathrm{~kg}$ & 0.61 \\
\hline
\end{tabular}

Slump $=35 \mathrm{~mm}$

\subsubsection{3 \% Replacement}

For 3 cubes we require

Cement $=1300 \mathrm{~g}-39 \mathrm{~g}=1261 \mathrm{~g}$

$=1287$ × $3=3783 \mathrm{~g}=3.78 \mathrm{~kg}$

Chalk $=39 \times 3=117 \mathrm{~g}$

Fine aggregate $=1.9 \times 3=5.7 \mathrm{~kg}$

Coarse aggregate $=3.8 \times 3=11.4 \mathrm{~kg}$

Water $=0.6 \times 3=1.81$

Table 6: Mix Design Proportions for 3 cubes of sizes $150 \mathrm{~mm} \times 150 \mathrm{~mm} \times 150 \mathrm{~mm}$ for $3 \%$ replacement of chalk powder with cement

\begin{tabular}{|l|l|l|l|l|l|}
\hline $\begin{array}{l}\text { W/C } \\
\text { ratio }\end{array}$ & Cement & $\begin{array}{l}\text { Chalk } \\
\text { powder }\end{array}$ & $\begin{array}{l}\text { Fine } \\
\text { Aggregate }\end{array}$ & $\begin{array}{l}\text { Coarse } \\
\text { Aggregate }\end{array}$ & Water \\
\hline 0.5 & $3.78 \mathrm{~kg}$ & $117 \mathrm{~g}$ & $5.7 \mathrm{~kg}$ & $11.4 \mathrm{~kg}$ & 1.81 \\
\hline
\end{tabular}

Slump $=30 \mathrm{~mm}$

\subsection{Replacement of Coconut Fiber with Cement}

\subsection{1 $1 \%$ Replacement}

For 3 cubes we require

Cement $=1300 \mathrm{~g}-13 \mathrm{~g}=1287 \mathrm{~g}$

$=1287 \times 3=3861 \mathrm{~g}=3.86 \mathrm{~kg}$

Coconut fiber $=13 \times 3=39 \mathrm{~g}$

Fine aggregate $=1.9 \times 3=5.7 \mathrm{~kg}$

Coarse aggregate $=3.8 \times 3=11.4 \mathrm{~kg}$

Water $=0.6 \times 3=1.81$
Table 7: Mix Design Proportions for 3 cubes of sizes $150 \mathrm{~mm} \times 150 \mathrm{~mm} \times 150 \mathrm{~mm}$ for $1 \%$ replacement of coconut fiber with cement

\begin{tabular}{|l|l|l|l|l|l|}
\hline $\begin{array}{l}\text { W/C } \\
\text { ratio }\end{array}$ & Cement & $\begin{array}{l}\text { Coconu } \\
\text { t fiber }\end{array}$ & $\begin{array}{l}\text { Fine } \\
\text { Aggregat } \\
\text { e }\end{array}$ & $\begin{array}{l}\text { Coarse } \\
\text { Aggreg } \\
\text { ate }\end{array}$ & $\begin{array}{l}\text { Wate } \\
\mathrm{r}\end{array}$ \\
\hline 0.5 & $3.86 \mathrm{~kg}$ & $39 \mathrm{~g}$ & $5.7 \mathrm{~kg}$ & $11.4 \mathrm{~kg}$ & 1.81 \\
\hline
\end{tabular}

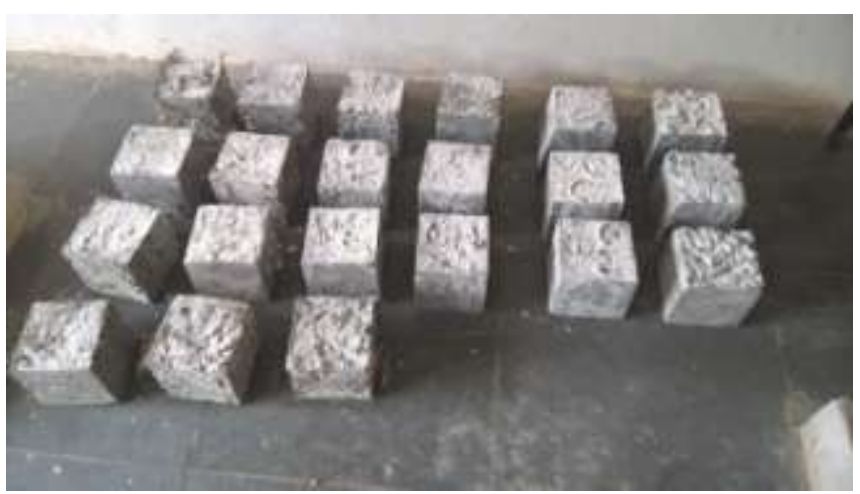

Fig 4: Cubes before testing

\subsection{2 $2 \%$ Replacement}

For 3 cubes we require

Cement $=1300 \mathrm{~g}-26 \mathrm{~g}=1274 \mathrm{~g}$ $=1274 \times 3=3822 \mathrm{~g}=3.82 \mathrm{~kg}$

Coconut fiber $=26 \times 3=78 \mathrm{~g}$

Fine aggregate $=1.9 \times 3=5.7 \mathrm{~kg}$

Coarse aggregate $=3.8 \times 3=11.4 \mathrm{~kg}$

Water $=0.6 \times 3=1.81$

Table 8: Mix Design Proportions for 3 cubes of sizes $150 \mathrm{~mm} \times 150 \mathrm{~mm} \times 150 \mathrm{~mm}$ for $2 \%$ replacement of coconut fiber with cement

\begin{tabular}{|l|l|l|l|l|l|}
\hline $\begin{array}{l}\text { W/C } \\
\text { ratio }\end{array}$ & Cement & $\begin{array}{l}\text { Coconu } \\
\text { t fiber }\end{array}$ & $\begin{array}{l}\text { Fine } \\
\text { Aggregat } \\
\text { e }\end{array}$ & $\begin{array}{l}\text { Coarse } \\
\text { Aggregat } \\
\text { e }\end{array}$ & $\begin{array}{l}\text { Wate } \\
\mathrm{r}\end{array}$ \\
\hline 0.5 & $3.82 \mathrm{~kg}$ & $78 \mathrm{~g}$ & $5.7 \mathrm{~kg}$ & $11.4 \mathrm{~kg}$ & 1.81 \\
\hline
\end{tabular}

Slump $=16 \mathrm{~mm}$

\subsection{3 $3 \%$ Replacement}

For 3 cubes we require Cement $=1300 \mathrm{~g}-39 \mathrm{~g}=1261 \mathrm{~g}$ $=1261 \times 3=3783 \mathrm{~g}=3.78 \mathrm{~kg}$

Coconut fiber $=39 \times 3=117 \mathrm{~g}$ Fine aggregate $=1.9 \times 3=5.7 \mathrm{~kg}$ Coarse aggregate $=3.8 \times 3=11.4 \mathrm{~kg}$ Water $=0.6 \times 3=1.81$

Table 9: Mix Design Proportions for 3 cubes of sizes $150 \mathrm{~mm} \times 150 \mathrm{~mm} \times 150 \mathrm{~mm}$ for $3 \%$ replacement of coconut fiber with cement

\begin{tabular}{|l|l|l|l|l|l|}
\hline $\begin{array}{l}\text { W/C } \\
\text { ratio }\end{array}$ & Cement & $\begin{array}{l}\text { Coconut } \\
\text { fiber }\end{array}$ & $\begin{array}{l}\text { Fine } \\
\text { Aggregate }\end{array}$ & $\begin{array}{l}\text { Coarse } \\
\text { Aggregate }\end{array}$ & Water \\
\hline 0.5 & $3.78 \mathrm{~kg}$ & $117 \mathrm{~g}$ & $5.7 \mathrm{~kg}$ & $11.4 \mathrm{~kg}$ & 1.81 \\
\hline
\end{tabular}

Slump $=19 \mathrm{~mm}$ 


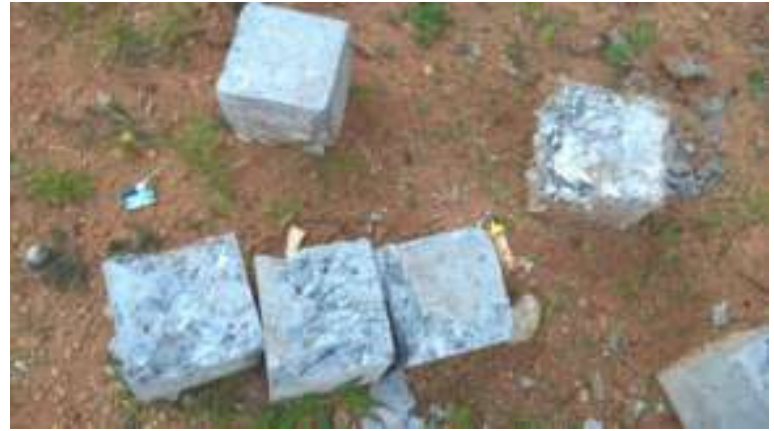

Fig 5: Cubes after testing

\section{RESULT}

\subsection{Conventional Concrete}

Table 10: Average stress of conventional concrete

\begin{tabular}{|l|l|l|l|}
\hline $\begin{array}{l}\text { Conventional } \\
\text { concrete }\end{array}$ & Cube 1 & Cube 2 & Cube 3 \\
\hline Load $(\mathrm{KN})$ & 585 & 605 & 610 \\
\hline Stress $\left(\mathrm{N} / \mathrm{mm}^{2}\right)$ & 26 & 26.889 & 27.111 \\
\hline & & Average $=$ & 26.667 \\
\hline
\end{tabular}

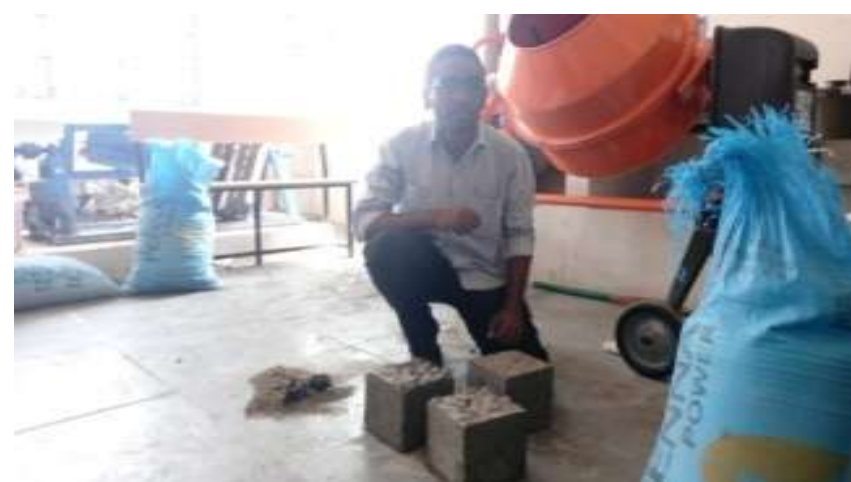

Fig 6: Representation of conventional concrete cubes prepared

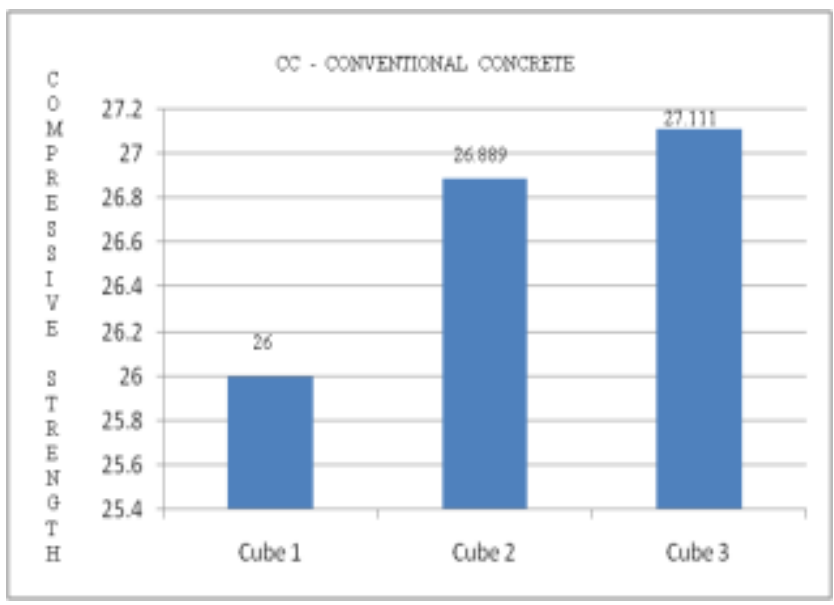

Graph 1: Representation of stress of conventional concrete after 28 days

The above graph shows representation of compressive strength of conventional concrete cubes tested after 28 days. The compressive strength of conventional concrete cubes obtained is $26.667 \mathrm{~N} / \mathrm{mm}^{2}$.

\subsection{Replacement of Chalk Powder with Cement}

\subsection{1 $1 \%$ Replacement}

Table 11: Average stress of $1 \%$ replacement of chalk powder with cement

\begin{tabular}{|l|l|l|l|}
\hline $\begin{array}{l}1 \\
\text { replacement of } \\
\text { chalk powder } \\
\text { with cement }\end{array}$ & Cube 1 & Cube 2 & Cube 3 \\
\hline Load $(\mathrm{KN})$ & 560 & 575 & 590 \\
\hline Stress $\left(\mathrm{N} / \mathrm{mm}^{2}\right)$ & 24.889 & 25.556 & 26.222 \\
\hline & & Average $=$ & 25.556 \\
\hline
\end{tabular}

\subsection{2 $2 \%$ Replacement}

Table 12: Average stress of $2 \%$ replacement of chalk powder with cement

\begin{tabular}{|l|l|l|l|}
\hline $\begin{array}{l}2 \% \text { replacement } \\
\text { of chalk powder } \\
\text { with cement }\end{array}$ & Cube 1 & Cube 2 & Cube 3 \\
\hline Load $(\mathrm{KN})$ & 565 & 585 & 600 \\
\hline Stress $\left(\mathrm{N} / \mathrm{mm}^{2}\right)$ & 25.111 & 26 & 26.667 \\
\hline & & Average $=$ & 25.926 \\
\hline
\end{tabular}

\subsection{3 $3 \%$ Replacement}

Table 13: Average stress of 3\% replacement of chalk powder with cement

\begin{tabular}{|l|l|l|l|}
\hline $\begin{array}{l}3 \text { \% replacement } \\
\text { of chalk powder } \\
\text { with cement }\end{array}$ & Cube 1 & Cube 2 & Cube 3 \\
\hline Load $(\mathrm{KN})$ & 540 & 565 & 555 \\
\hline Stress $\left(\mathrm{N} / \mathrm{mm}^{2}\right)$ & 24 & 25.111 & 24.667 \\
\hline & & Average $=$ & 24.593 \\
\hline
\end{tabular}

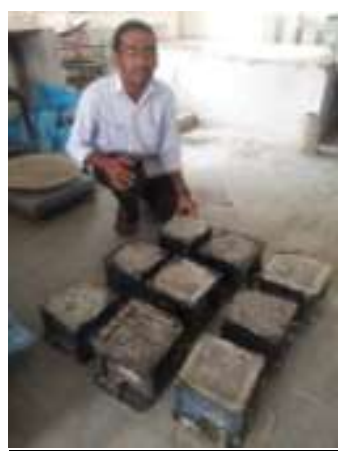

Fig 7: Representation of cubes prepared by chalk powder replacing with concrete

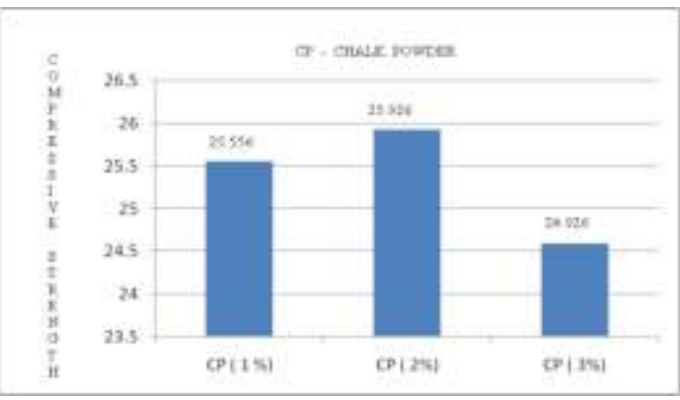

Graph 2: Representation of stress of $\mathrm{CP}(1 \%), \mathrm{CP}(2 \%), \mathrm{CP}$ $(3 \%)$ 
The above graph shows the representation of compressive strength of CPRC cubes tested after 28 days. The compressive strength of CPRC cubes (1\%), CPRC cubes (2\%), CPRC cubes (3\%) obtained are $25.556 \mathrm{~N} / \mathrm{mm}^{2}$, $25.926 \mathrm{~N} / \mathrm{mm}^{2}$ and $24.593 \mathrm{~N} / \mathrm{mm}^{2}$ respectively. By adding $\mathrm{CP}(2 \%)$ there is an increment by $1.5 \%$ in compressive strength value when compared to $\mathrm{CP}(1 \%)$. By adding $\mathrm{CP}$ (3\%) there is a decrement by $5.4 \%$ in compressive strength value when compared to $\mathrm{CP}(2 \%)$.

\subsection{Replacement of Coconut Fiber with Cement}

\subsection{1 $1 \%$ Replacement}

Table 14: Average stress of $1 \%$ replacement of coconut fiber with cement

\begin{tabular}{|l|l|l|l|}
\hline $\begin{array}{l}1 \% \text { replacement } \\
\text { of coconut fiber } \\
\text { with cement }\end{array}$ & Cube 1 & Cube 2 & Cube 3 \\
\hline Load $(\mathrm{KN})$ & 580 & 595 & 590 \\
\hline Stress $\left(\mathrm{N} / \mathrm{mm}^{2}\right)$ & 25.778 & 26.444 & 26.222 \\
\hline & & Average $=$ & 26.148 \\
\hline
\end{tabular}

\subsection{2 $2 \%$ Replacement}

Table 15: Average stress of $2 \%$ replacement of coconut fiber with cement

\begin{tabular}{|l|l|l|l|}
\hline $\begin{array}{l}2 \% \text { replacement } \\
\text { of coconut fiber } \\
\text { with cement }\end{array}$ & Cube 1 & Cube 2 & Cube 3 \\
\hline Load $(\mathrm{KN})$ & 590 & 610 & 630 \\
\hline Stress $\left(\mathrm{N} / \mathrm{mm}^{2}\right)$ & 26.222 & 27.111 & 28 \\
\hline & & Average $=$ & 27.111 \\
\hline
\end{tabular}

\subsection{3 $3 \%$ Replacement}

Table 16: Average stress of $3 \%$ replacement of coconut fiber with cement

\begin{tabular}{|l|l|l|l|}
\hline $\begin{array}{l}3 \% \text { replacement } \\
\text { of coconut fiber } \\
\text { with cement }\end{array}$ & Cube 1 & Cube 2 & Cube 3 \\
\hline Load $(\mathrm{KN})$ & 625 & 605 & 645 \\
\hline Stress $\left(\mathrm{N} / \mathrm{mm}^{2}\right)$ & 27.778 & 26.889 & 28.667 \\
\hline & & Average $=$ & 27.778 \\
\hline
\end{tabular}

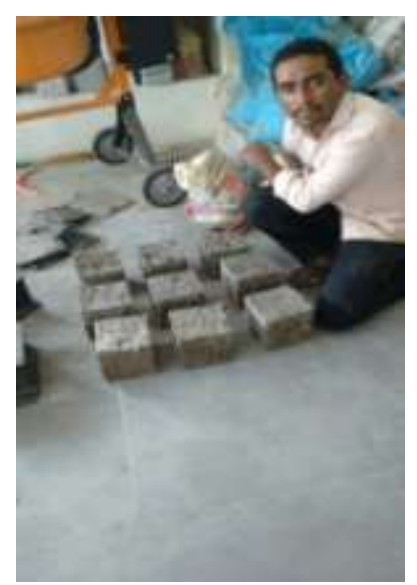

Fig 8: Representation of cubes prepared by coconut fiber replacing with cement

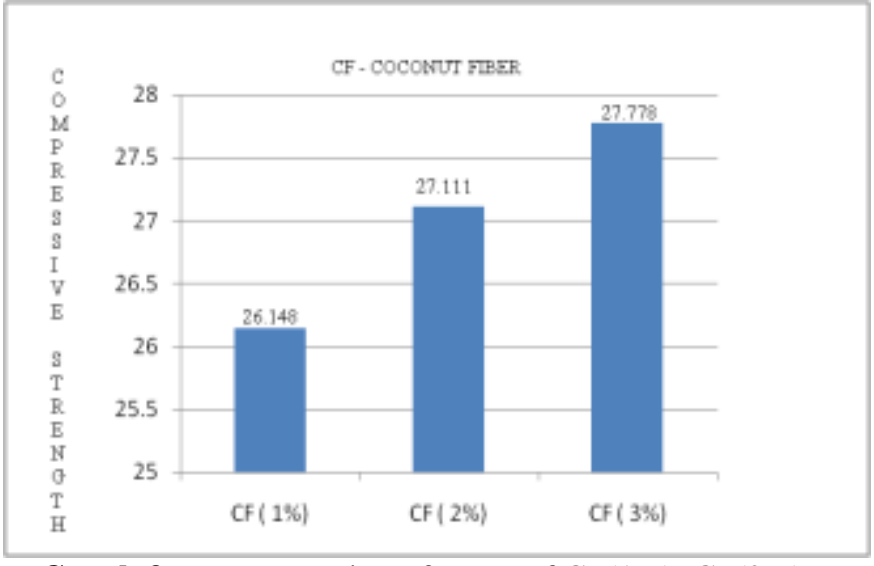

Graph 3: Representation of stress of $\mathrm{CF}(1 \%), \mathrm{CF}(2 \%)$, $\mathrm{CF}(3 \%)$

The above graph shows the representation of compressive strength of CFRC cubes tested after 28 days. The compressive strength of CFRC cubes (1\%), CFRC cubes (2\%), CFRC cubes (3\%) obtained are $26.148 \mathrm{~N} / \mathrm{mm}^{2}$, $27.111 \mathrm{~N} / \mathrm{mm}^{2}$ and $27.778 \mathrm{~N} / \mathrm{mm}^{2}$ respectively. By adding $\mathrm{CF}(2 \%)$ there is an increment by $3.7 \%$ in compressive strength value when compared to $\mathrm{CF}(1 \%)$. By adding $\mathrm{CF}$ $(3 \%)$ there is increment by $2.5 \%$ in compressive strength value when compared to $\mathrm{CF}(2 \%)$.

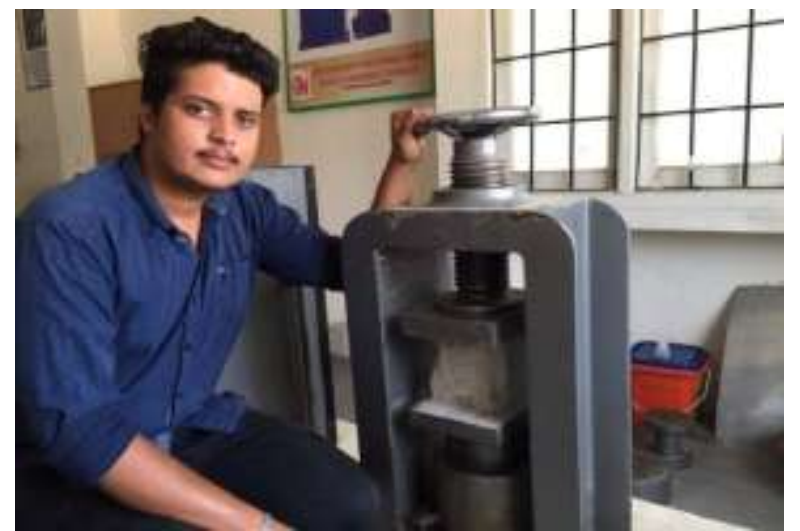

Fig 9: Testing of conventional concrete cubes

\subsection{Comparison of Conventional Concrete with}

\section{Chalk Powder}

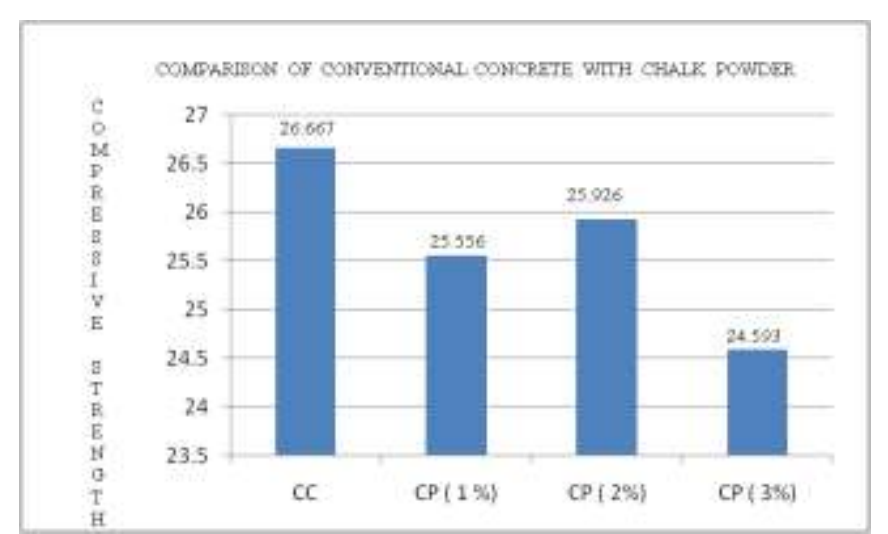

Graph 4: Representation of CC, CP (1\%), CP (2\%), $\mathrm{CP}(3 \%)$ 
The above graph represents the comparison of compressive strength of conventional concrete with Chalk powder. The compressive strength of $\mathrm{CP}(1 \%)$ is $25.556 \mathrm{~N} / \mathrm{mm}^{2}$ which is less than CC i.e $26.667 \mathrm{~N} / \mathrm{mm}^{2}$. The compressive strength of CF (2\%) is $25.926 \mathrm{~N} / \mathrm{mm}^{2}$ which is less than CC i.e 26.667 $\mathrm{N} / \mathrm{mm}^{2}$. The compressive strength of CF $(3 \%)$ is 24.593 $\mathrm{N} / \mathrm{mm}^{2}$ which is less than CC i.e $26.667 \mathrm{~N} / \mathrm{mm}^{2}$. There is a decrement by $4.4 \%$ in compressive strength of $\mathrm{CP}(1 \%)$ when compared to $\mathrm{CC}$. There is a decrement by $2.8 \%$ in compressive strength of $\mathrm{CP}(2 \%)$ when compared to $\mathrm{CC}$. There is a decrement by $8.4 \%$ in compressive strength of $\mathrm{CP}$ (3\%) when compared to CC.

\subsection{Comparison of Conventional Concrete with}

\section{Coconut Fiber}

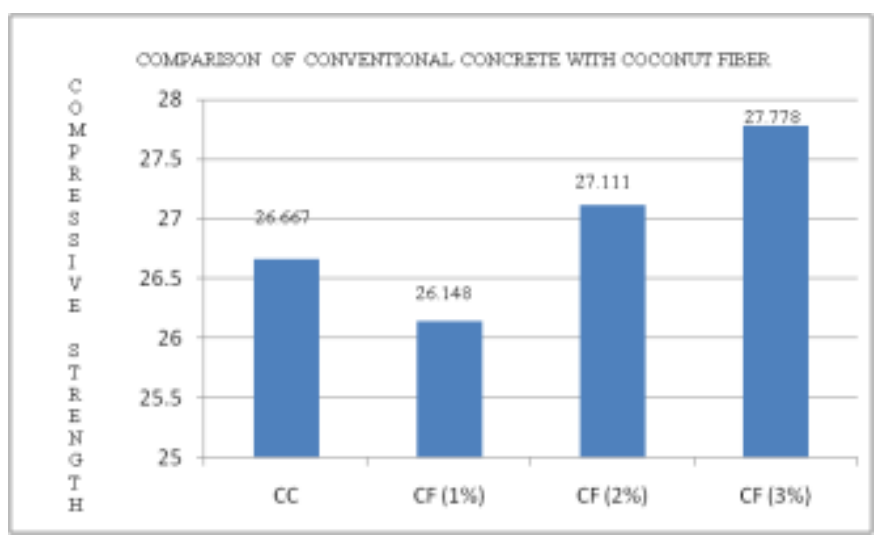

Graph 5: Representation of stress of CC, CF (1\%), CF $(2 \%), \mathrm{CF}(3 \%)$

The above graph represents the comparison of compressive strength of conventional concrete with coconut fiber. The compressive strength of CF $(1 \%)$ is $26.148 \mathrm{~N} / \mathrm{mm}^{2}$ which is less than CC i.e $26.667 \mathrm{~N} / \mathrm{mm}^{2}$. The compressive strength of $\mathrm{CF}(2 \%)$ is $27.111 \mathrm{~N} / \mathrm{mm}^{2}$ which is more than $\mathrm{CC}$ i.e 26.667 $\mathrm{N} / \mathrm{mm}^{2}$. The compressive strength of $\mathrm{CF}(3 \%)$ is 27.778 $\mathrm{N} / \mathrm{mm}^{2}$ which is more than CC i.e $26.667 \mathrm{~N} / \mathrm{mm}^{2}$. There is a decrement by $2 \%$ in compressive strength of $\mathrm{CF}(1 \%)$ when compared to $\mathrm{CC}$. There is a increment by $1.7 \%$ in compressive strength of $\mathrm{CF}(2 \%)$ when compared to $\mathrm{CC}$. There is a increment by $4.2 \%$ in compressive strength of $\mathrm{CF}$ (3\%) when compared to CC.

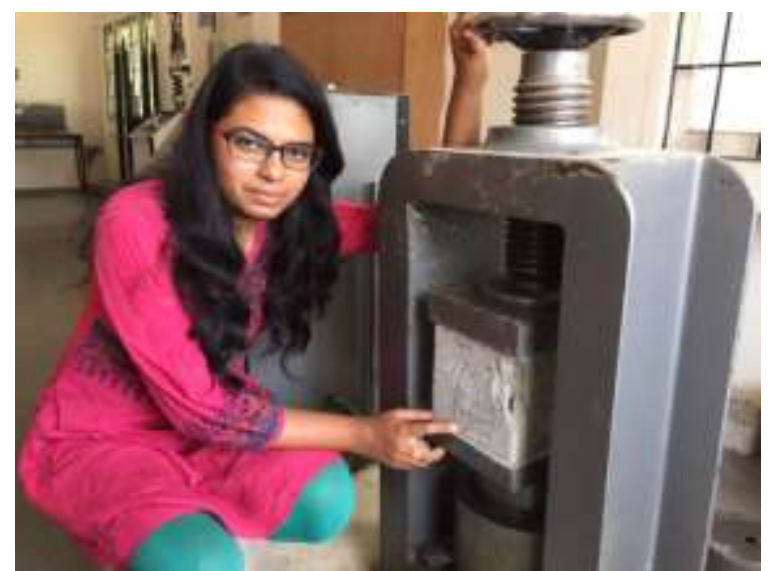

Fig 10: Testing of cubes prepared by using chalk powder

\subsection{Consolidated Report}

The below graph represents the comparison of compressive strength of conventional concrete, chalk powder and coconut fiber .The compressive strength of $\mathrm{CP}(1 \%)$ is $25.556 \mathrm{~N} / \mathrm{mm}^{2}$ which is less than CC i.e $26.667 \mathrm{~N} / \mathrm{mm}^{2}$. The compressive strength of $\mathrm{CF}(2 \%)$ is $25.926 \mathrm{~N} / \mathrm{mm}^{2}$ which is less than CC i.e $26.667 \mathrm{~N} / \mathrm{mm}^{2}$. The compressive strength of CF (3\%) is $24.593 \mathrm{~N} / \mathrm{mm}^{2}$ which is less than CC i.e 26.667 $\mathrm{N} / \mathrm{mm}^{2}$. There is a decrement by $4.4 \%$ in compressive strength of $\mathrm{CP}(1 \%)$ when compared to $\mathrm{CC}$. There is a decrement by $2.8 \%$ in compressive strength of $\mathrm{CP}(2 \%)$ when compared to $\mathrm{CC}$. There is a decrement by $8.4 \%$ in compressive strength of $\mathrm{CP}(3 \%)$ when compared to $\mathrm{CC}$. The compressive strength of CF $(1 \%)$ is $26.148 \mathrm{~N} / \mathrm{mm}^{2}$ which is less than $\mathrm{CC}$ i.e $26.667 \mathrm{~N} / \mathrm{mm}^{2}$. The compressive strength of $\mathrm{CF}(2 \%)$ is $27.111 \mathrm{~N} / \mathrm{mm}^{2}$ which is more than CC i.e $26.667 \mathrm{~N} / \mathrm{mm}^{2}$. The compressive strength of CF (3\%) is $27.778 \mathrm{~N} / \mathrm{mm}^{2}$ which is more than CC i.e $26.667 \mathrm{~N} / \mathrm{mm}^{2}$. There is a decrement by $2 \%$ in compressive strength of $\mathrm{CF}$ (1\%) when compared to CC. There is a increment by $1.7 \%$ in compressive strength of $\mathrm{CF}(2 \%)$ when compared to $\mathrm{CC}$. There is a increment by $4.2 \%$ in compressive strength of $\mathrm{CF}$ (3\%) when compared to $\mathrm{CC}$.

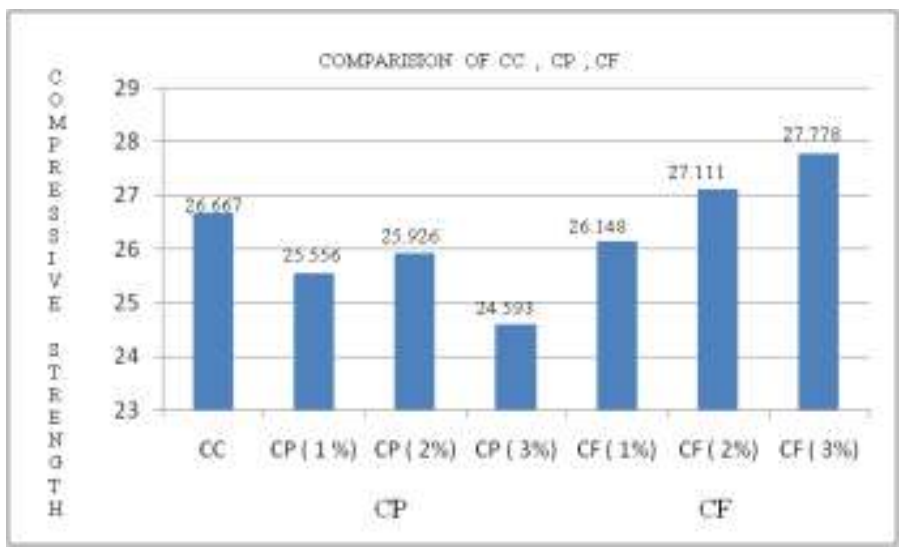

Graph 6: Representation of stress of CC, CP (1\%), CP (2\%), CP (3\%), CF (1\%), CF ( $2 \%), \mathrm{CF}(3 \%)$

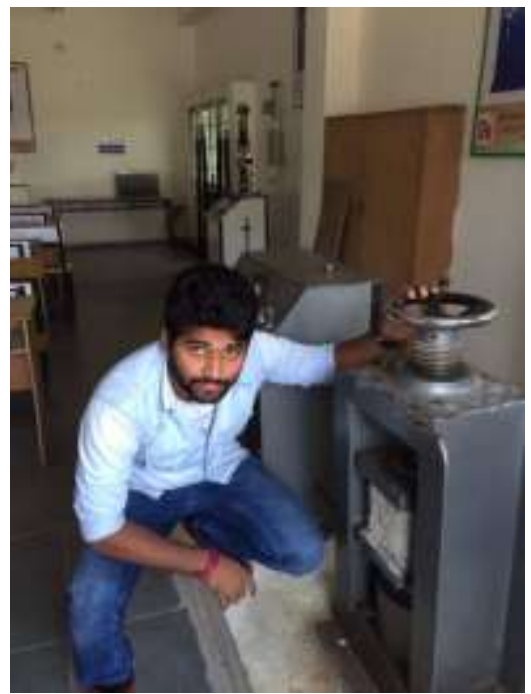

Fig 11: Testing of cubes prepared by using coconut fiber 


\section{CONCLUSION}

We conclude that by doing this project there is increment in addition of chalk powder with $2 \%$ but the results shows that by adding more percentage of chalk powder there is decrement in compressive strength. There is increment increase in addition of coconut fiber with $1 \%, 2 \%, 3 \%$ in compressive strength.

The compressive strength of CP $(1 \%)$ is $25.556 \mathrm{~N} / \mathrm{mm}^{2}$ which is less than CC i.e $26.667 \mathrm{~N} / \mathrm{mm}^{2}$. The compressive strength of CF (2\%) is $25.926 \mathrm{~N} / \mathrm{mm}^{2}$ which is less than CC i.e $26.667 \mathrm{~N} / \mathrm{mm}^{2}$. The compressive strength of CF (3\%) is $24.593 \mathrm{~N} / \mathrm{mm}^{2}$ which is less than CC i.e $26.667 \mathrm{~N} / \mathrm{mm}^{2}$. There is a decrement by $4.4 \%$ in compressive strength of $\mathrm{CP}$ (1\%) when compared to CC. There is a decrement by $2.8 \%$ in compressive strength of $\mathrm{CP}(2 \%)$ when compared to CC. There is a decrement by $8.4 \%$ in compressive strength of CP (3\%) when compared to CC. The compressive strength of CF $(1 \%)$ is $26.148 \mathrm{~N} / \mathrm{mm}^{2}$ which is less than CC i.e 26.667 $\mathrm{N} / \mathrm{mm}^{2}$. The compressive strength of $\mathrm{CF}(2 \%)$ is 27.111 $\mathrm{N} / \mathrm{mm}^{2}$ which is more than CC i.e $26.667 \mathrm{~N} / \mathrm{mm}^{2}$. The compressive strength of $\mathrm{CF}(3 \%)$ is $27.778 \mathrm{~N} / \mathrm{mm}^{2}$ which is more than CC i.e $26.667 \mathrm{~N} / \mathrm{mm}^{2}$. There is a decrement by $2 \%$ in compressive strength of $\mathrm{CF}(1 \%)$ when compared to CC. There is a increment by $1.7 \%$ in compressive strength of CF (2\%) when compared to CC. There is a increment by $4.2 \%$ in compressive strength of $\mathrm{CF}(3 \%)$ when compared to CC.

\section{FURTHER SCOPE}

The compressive strength of concrete may be increased by addition of different percentages of chalk powder and coconut fiber or by adding steel fibers or any other admixture to the concrete. The compressive strength may be increased by addition of combination of chalk powder and coconut fiber to the concrete.

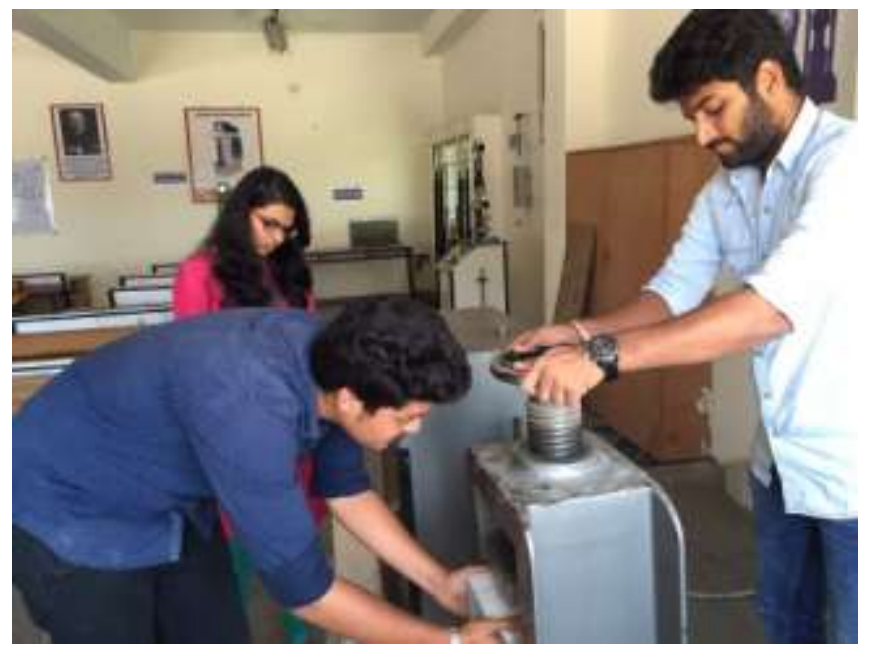

Fig 12: Testing of cubes in CTM

\section{REFERENCES}

[1]. Concrete Technology by M.S. Shetty text book

[2]. IS 456-2000 (Design of Reinforced Concrete Structures) code book
[3]. IS 10262 (Concrete mix proportioning) code book [4]. IS 383 (Specification for fine and coarse aggregate from natural sources for concrete) code book

[5]. THE EFFECT OF ADDITION OF LIMESTONE POWDER ON THE PROPERTIES OF SELF COMPACTING CONCRETE, Vol. 2, Issue 9, September 2013, ISSN: 2319-8753

[6]. EFFECT OF COCONUT FIBERS ON THE PROPERTIES OF CONCRETE pISSN: 2321-7308, eISSN: 2319-1163, Volume: 03 Issue: 12 | Dec-2014

[7]. Effect of coconut fiber and fly ash on concrete 2349784X, Volume 2 | Issue 3 | September 2015.

[8]. Effect of coconut fiber ash on strength properties of concrete ISSN: 2248-9622, Vol. 5, Issue 4, ( Part -1) April 2015

\section{BIOGRAPHIES}

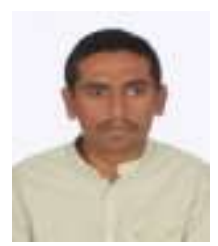

VINEET SINGH T, Student, GNITC, Hyderabad.

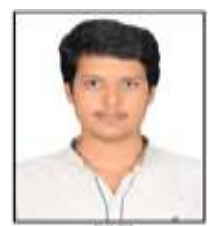

TIWARI RAKESH PRASAD, Student, GNITC, Hyderabad.

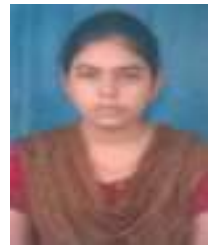

SURE MOUNIKA, Student, GNITC, Hyderabad.

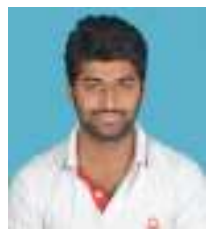

VEMULA SUJEETH KUMAR REDDY, Student, GNITC, Hyderabad. 